\title{
Vertebral artery loop formation causing severe cervical nerve root compression
}

\section{Figure 1 Oblique sagittal T2 sequence through the right cervical neural foramina}

\section{Figure 2 Axial 3-dimensional T2 sequence through the C3-C4 neural foramina}

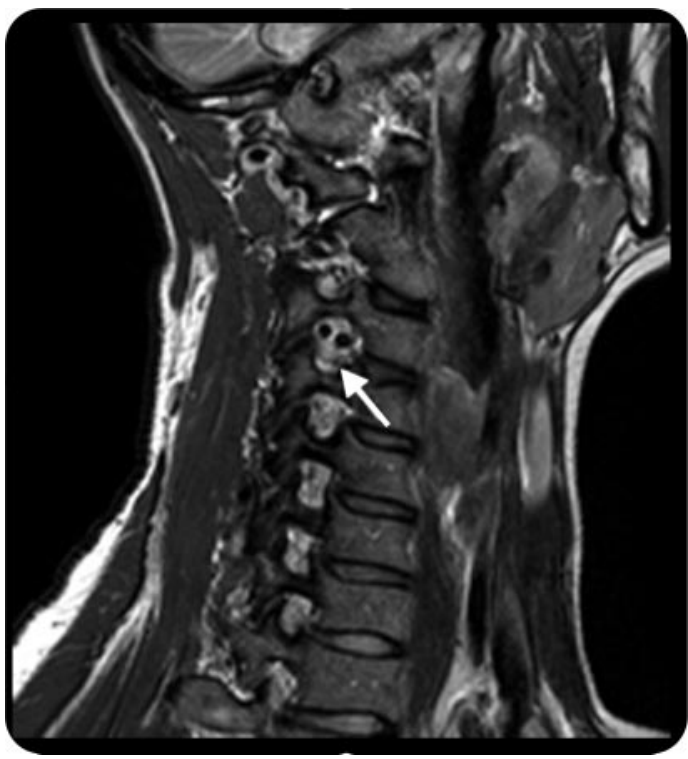

Vertebral artery flow void within the right C3-C4 neural foramen inferiorly displaces the right $\mathrm{C} 4$ nerve root (arrow).

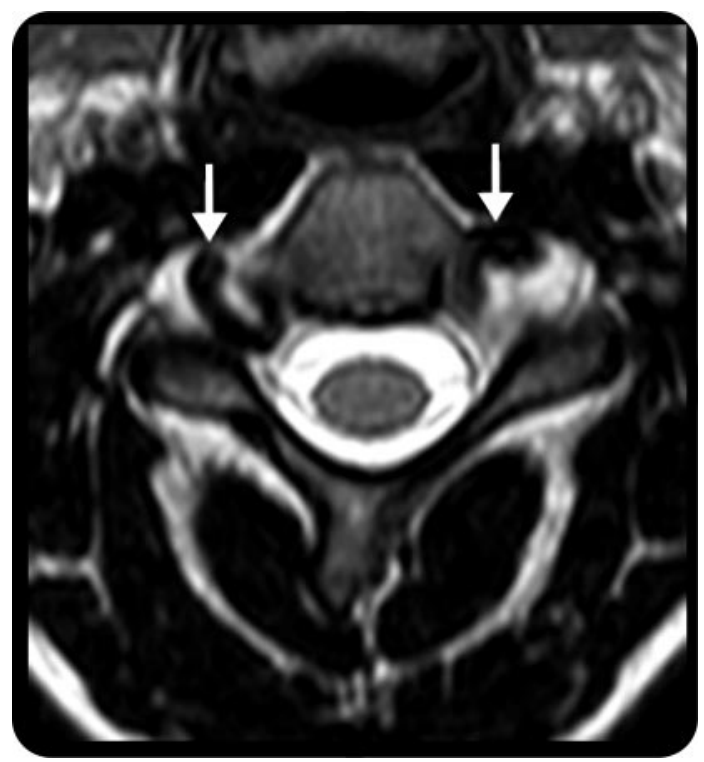

Vertebral artery loops within the C3-C4 neural foramina (arrows). C6 nerve roots (not shown) were also involved, likely explaining her arm pain symptoms, which improved with medical management.

A 35-year-old woman presented with 10 years of stabbing pain in her neck and upper back above her right scapula, sometimes radiating into both arms. Examination results were normal. Somatosensory evoked potentials showed significantly prolonged latency of the right C4 nerve root. Cervical spine MRI demonstrated tortuous vertebral arteries looping most notably into the $\mathrm{C} 3-\mathrm{C} 4$ neural foramina bilaterally, compressing the C4 nerve roots, right worse than left (figures 1 and 2).

Vertebral artery loop formation is an uncommon cause of cervicobrachial neuralgia caused by direct compression of the nerve root. ${ }^{1}$ Surgical decompression is usually reserved for cases that fail conservative treatment. $^{2}$

\section{James R. Fink, MD, Jessica Y. Leung, MD, Claire J. Creutzfeldt, MD, Seattle, WA}

Disclosure: Dr. Fink is an AUR-GERRAF Award recipient sponsored by GE Healthcare. Dr. Leung and Dr. Creutzfeldt report no disclosures.

Address correspondence and reprint requests to Dr. Jessica Y. Leung, University of Washington Medical Center, Box 357115, Seattle, WA 98195-7115; jyleung@uw.edu

1. Paksoy Y, Levendoglu FD, Ogun CO, Ustun ME, Ogun TC. Vertebral artery loop formation: a frequent cause of cervicobrachial pain. Spine 2003;28:1183-1188

2. Sakaida H, Okada M, Yamamoto A. Vascular reconstruction of a vertebral artery loop causing cervical radiculopathy and vertebrobasilar insufficiency. J Neurosurg 2001;94:145-149. 


\section{Neurology}

\section{Vertebral artery loop formation causing severe cervical nerve root compression}

James R. Fink, Jessica Y. Leung and Claire J. Creutzfeldt

Neurology 2010;75;192

DOI 10.1212/WNL.0b013e3181e7ca44

\section{This information is current as of July 12, 2010}

\section{Updated Information \& Services}

References

Subspecialty Collections

Permissions \& Licensing

Reprints including high resolution figures, can be found at: http://n.neurology.org/content/75/2/192.full

This article cites 2 articles, 0 of which you can access for free at: http://n.neurology.org/content/75/2/192.full\#ref-list-1

This article, along with others on similar topics, appears in the following collection(s): Evoked Potentials/Somatosensory http://n.neurology.org/cgi/collection/evoked_potentials-somatosensory MRI

http://n.neurology.org/cgi/collection/mri

Neuropathic pain

http://n.neurology.org/cgi/collection/neuropathic_pain

Information about reproducing this article in parts (figures,tables) or in its entirety can be found online at:

http://www.neurology.org/about/about_the_journal\#permissions

Information about ordering reprints can be found online:

http://n.neurology.org/subscribers/advertise

Neurology $®$ is the official journal of the American Academy of Neurology. Published continuously since 1951, it is now a weekly with 48 issues per year. Copyright . All rights reserved. Print ISSN: 0028-3878. Online ISSN: 1526-632X.

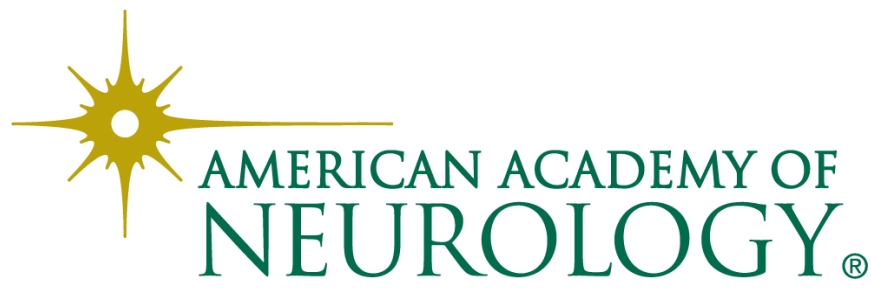

